\title{
Baseline Specimens of Erosion and Abrasion Studies
}

\author{
Hayati Ishak ${ }^{1, \odot ~ J a m e s ~ F i e l d ~}{ }^{2, \odot}$ Matthew German ${ }^{3}$ \\ ${ }^{1}$ Centre of Comprehensive Care Studies, Faculty of Dentistry, \\ Universiti Teknologi MARA, Selangor, Malaysia \\ ${ }^{2}$ Department of Restorative Dentistry School of Dentistry, Cardiff \\ University, Cardiff, United Kingdom \\ ${ }^{3}$ School of Dental Sciences, Translational and Clinical Research \\ Institute, Newcastle University, Newcastle, United Kingdom
}

\begin{abstract}
Address for correspondence Hayati Ishak, BDS (Malaya), MClinDent in Restorative Dentistry (Newcastle, UK), International Training Fellowship (RCS England), Faculty of Dentistry, Universiti Teknologi MARA (UiTM), Jalan Hospital, 47000 Sg Buloh, Selangor Darul Ehsan, Malaysia (e-mail: hayati66@uitm.edu.my).
\end{abstract}

\begin{abstract}
Keywords

- bearing area parameters

- enamel

- silicon carbide abrasive papers

- surface roughness

The difficulty in obtaining human teeth that are caries-free that have similar environmental exposure, e.g., diet intake and water fluoridation has lead researchers to opt for bovine teeth as a substitute for erosion studies. Bovine mandibular incisors are readily available at abattoirs and often originate from the same region and are likely to consume similar dietary intake. The bovine teeth for erosion or abrasion studies usually undergo specimen preparation to produce a "flat surface" baseline specimen. Among other terms used to define baseline specimens for erosion and abrasion studies include phrases like "optically flat" and "flat and smooth surface." However, these terms might have no quantitative value as it does not justify the actual surface characteristics of the prepared flattened surface. In dentistry, roughness average ( $\mathrm{Ra}$ ) is the most commonly used parameter when reporting the roughness of specimens Reporting Ra alone might not be sufficient as it does not provide information regarding the surface texture as there is no distinction between valleys and peaks, nor does it provide information about the core structure of a material unlike the bearing area curve. The incorporation of Ra and BAP values in baseline specimens has the potential in predicting the wear or lubricating potential of these specimens. Furthermore, standardization of baseline specimens by acknowledging its surface roughness values ensures comparability of erosion and abrasion studies as different specimen preparation technique might influence the outcome or results of research.
\end{abstract}

\section{Introduction}

Human teeth that are caries-free and originate from the same environment are challenging to obtain in sufficient numbers. ${ }^{1}$ Currently, most erosion and abrasion studies use bovine mandibular incisors as a substitute for human teeth. Bovine teeth are more readily available ${ }^{2}$ and often originate from the same region and environment. ${ }^{1}$ Furthermore, bovine teeth do not suffer from caries. ${ }^{3}$

In erosion and abrasion studies, the human or bovine teeth require some form of preparation before exposing these specimens to any wear or acidic challenges. The specimen preparation process typically involves the sectioning and embedding of teeth in a mold. Once embedding is completed, these specimens are subjected to a specific lapping and polishing procedure to produce a flat surface. The flat surface is usually described as the baseline. The terms that have been used to define the baseline for specimens are as follows; "flat surface,"4 "optically flat," " "flat and smooth surface," ${ }^{\prime 6}$ and "polished and ground flat." ${ }^{7}$ However, these terms do not represent the actual surface characteristics of a specimen. According to Las Casas et al, even the most carefully published online

December 26, 2020
DOI https://doi.org/

$10.1055 / \mathrm{s}-0040-1721235$

ISSN 1305-7456. (c) 2020. European Journal of Dentistry.

This is an open access article published by Thieme under the terms of the Creative Commons Attribution-NonDerivative-NonCommercial-License, permitting copying and reproduction so long as the original work is given appropriate credit. Contents may not be used for commercial purposes, or adapted, remixed, transformed or built upon. (https:// creativecommons.org/licenses/by-nc-nd/4.0/)

Thieme Medical and Scientific Publishers Pvt. Ltd., A-12, 2nd Floor, Sector 2, Noida-201301 UP, India 
prepared surface of any material would vary in surface texture when observed at a microscopic scale. ${ }^{8}$ Some studies go further to report the baseline based on the roughness average (Ra) value ${ }^{9,10}$ and the bearing area parameters (BAPs), ${ }^{9}$ while others simply optically inspect the baseline surfaces for visible defects. ${ }^{11}$

Due to the lack of standardization in lapping and polishing regimes employed in published studies, there is likely a considerable difference in enamel specimens at baseline. Silicon carbide abrasive papers of various particle sizes are commonly used for the lapping procedure with a range of lapping sequences reported; 600 grit $^{12} ; 800$ grit $^{4} ; 400$, 600, 800 grit $^{13} ; 800,1,200,4,000$ grit, $^{14}$ and $1,200,4,000$ grit. ${ }^{10}$ When polishing, aluminum oxide of different particle sizes has been used; for instance $0.05 \mu \mathrm{m}^{9,15} ; 1$ and $3 \mu \mathrm{m}^{16}$; $0.25,1,3$, and $6 \mu \mathrm{m}^{17}$ and $1 \mu \mathrm{m} .{ }^{18}$ However, further studies are required to determine the effects of different lapping and polishing methods on the surface roughness of enamel. To date, there have been no studies comparing the roughness parameters (Ra and BAPs) of bovine enamel specimens prepared using different silicon carbide abrasive papers. Results obtained will identify whether or not there is a need to standardize specimen preparation methods to ensure comparability between abrasion and erosion studies.

A possible way of establishing standardization of the specimens at baseline is by preparing the samples with (1) a standard lapping and polishing procedure and; (2) a standard depth of enamel removal. ${ }^{19}$ Thereafter, the measurement of roughness is needed to ensure the effectiveness of the lapping and polishing methods in producing baseline specimens with similar roughness values. Ra is a possible way of verifying the surface roughness for these specimens. However, the Ra value has its limitation as it only proves the mean values of roughness across the surface. The BAPs are a potentially valuable measurement for roughness as they can provide more comprehensive information regarding the surface characteristics, e.g., proportions of peaks and valleys of the surface. Furthermore, with the understanding of the roughness parameters of the specimens at baseline, the behavior of these specimens toward wear or fluid retention could be understood to a better degree. Field et al reported that although bovine and human enamel specimens had similar Ra at baseline and post-erosion, their BAP values differed. Human enamel specimens had more peaks whereas bovine enamel had more valleys at baseline suggesting that human enamel is likely to suffer early enamel loss upon erosive attacks when compared with bovine enamel. ${ }^{9}$

\section{Bovine Teeth and Human Teeth}

\section{Bovine Teeth As a Substitute for Human Teeth in Erosion or Abrasion Studies}

Several species are currently used as human substitutes for in vitro dental research involving dental hard tissues. ${ }^{20}$ These include shark, ${ }^{21} \mathrm{pig},{ }^{22}$ horse, ${ }^{23} \mathrm{cow},{ }^{24}$ sheep, ${ }^{23}$ and primate teeth. ${ }^{25}$

In recent years, almost half of in vitro erosion and abrasion studies have involved the use of bovine samples instead of human samples. ${ }^{26}$ Bovine mandibular incisors are used most often., ${ }^{2,27}$ The bovine mandibular incisors are readily available ${ }^{2}$ and have a large flat surface area without defects and carious lesions. ${ }^{28}$ Furthermore, a large flat surface can provide a specimen with a relatively uniform thickness of enamel. ${ }^{28}$ Their increased size compared with human teeth makes bovine teeth easier to handle and mechanically process. ${ }^{29}$ In contrast, human teeth are generally smaller, making it challenging to produce a specimen with a flat surface and uniform thickness of enamel. ${ }^{28}$ The mean mesiodistal width of a human central incisor was reported to be approximately $8.80 \mathrm{~mm}$ for males and $8.67 \mathrm{~mm}$ for females. ${ }^{30}$ In contrast, bovine incisors could reach up to $20 \mathrm{~mm}$ in mesiodistal width. The human teeth that have been used in erosion and abrasion studies include impacted third molars ${ }^{4,14}$ and nonimpacted third molars. ${ }^{31}$ The impacted molars exhibit areas with aprismatic enamel, surface irregularities, and projections and are less susceptible to acid dissolution when compared with nonimpacted third molars. ${ }^{14,32}$ Besides third molars the use of second molars, ${ }^{33}$ first molars, ${ }^{33}$ premolars, ${ }^{15,34}$ incisors, ${ }^{35-38}$ and deciduous teeth ${ }^{34,39,40}$ have also been reported as in - Table 1.

Other limitations of human teeth include the difficulty in obtaining sufficient quality since many are often extracted because of extensive caries and other defects. ${ }^{2}$ Not only that, but it is also challenging to control the age and source of the collected human teeth, which can influence the outcome measures of research..$^{28}$ Conversely, healthy bovine teeth are easier to obtain in sufficient quantities as they do not suffer from caries. ${ }^{3}$ For each reported study, the cattle from which the teeth are derived usually originate from the same region and are likely to be exposed to similar dietary and environmental factors. ${ }^{1}$ Hence, the bovine teeth used in research are more similar to one another than teeth obtained from different human subjects. ${ }^{1}$

\section{Enamel Microstructure of Human and Bovine Teeth}

Human dental enamel is the hardest tissue in the body being composed of 1 to $2 \%$ organic material, 3 to $4 \%$ of water, and

Table 1 The type of human teeth that have been used in previous erosion or abrasion studies

\begin{tabular}{|l|l|}
\hline \multicolumn{2}{|c|}{$\begin{array}{c}\text { Type of human teeth used in previous } \\
\text { erosion or abrasion studies }\end{array}$} \\
\hline 1. Incisors & $\begin{array}{l}\text { Huysmans and Thijssen, 2000, } \\
\text { Ceci et al, 2015; Jameel et al, } \\
2016\end{array}$ \\
\hline 2. Premolars & $\begin{array}{l}\text { Lussi et al, 2000; } \\
\text { Wongkhantee et al, 2006 }\end{array}$ \\
\hline 3. First molars & Lippert et al, 2004 \\
\hline 4. Second molars & Lipper et al, 2004 \\
\hline 5. Third molars & $\begin{array}{l}\text { Gans et al, 2000; } \\
\text { Newman et al,1974 }\end{array}$ \\
\hline 6. Impacted third molars & $\begin{array}{l}\text { Eisenburger and Addy, 2001; } \\
\text { Ganss et al, 2000 }\end{array}$ \\
\hline 7. Deciduous teeth & $\begin{array}{l}\text { Amaechi et al, 1999; Lussi et al, } \\
\text { 2000; Cherian et al, 2020 }\end{array}$ \\
\hline
\end{tabular}


92 to $96 \%$ of inorganic matter. ${ }^{41}$ The inorganic component consists mainly of calcium phosphate in the form of sizeable hexagonal hydroxyapatite (HAp) crystals, ${ }^{42}$ organized into rods, or prisms which are, in turn, perpendicular to the dentine-enamel junction. These rods form a keyhole-like structure measuring approximately $5 \mu \mathrm{m}$ in diameter. ${ }^{43,44}$ The hydroxyapatite crystals within the keyhole structure have different orientations in the head and tail area as in - Fig. 1.43,45

The mechanical properties of enamel are influenced by the enamel rod orientation. ${ }^{46,47}$ The angle between the amelodentinal junction (ADJ) and the enamel rods in bovine teeth ranges between 45 to 55 degrees ${ }^{20}$ whereas, in human teeth, it ranges from 70 to 90 degrees. ${ }^{48} \mathrm{Xu}$ et al reported that the occlusal section, which consists of enamels rods perpendicular to the surface was more resistant to erosion when compared with the axial section. ${ }^{47,48}$ In the axial section, approximately half the enamel prisms appeared parallel, and the other half appeared angled to the surface. ${ }^{47}$ In contrast, another study concluded that polished enamel samples showed no significant difference in erosive depth when tooth sides were compared. However, the distal surfaces of unpolished enamel specimens were more prone to acid dissolution when compared with the occlusal, buccal, and mesial surfaces. ${ }^{14}$

The hardness value of enamel was observed to be the highest at the external surface of enamel and decreased with the depth toward the ADJ, approximately 3.5 GPa and 2 to $2.5 \mathrm{GPa}$, respectively ${ }^{46}$ or by $17 \%{ }^{49}$ suggesting that hardness value differs between layers in a tooth and could have an effect on the rate of wear. ${ }^{49}$

A study by Wang et al using scanning electron microscopy revealed two main characteristics of bovine enamel that differs from human enamel, which are:

1. A larger size of fiber-like enamel crystals.

2. A complicated spatial-relationship between interprisms and prisms.

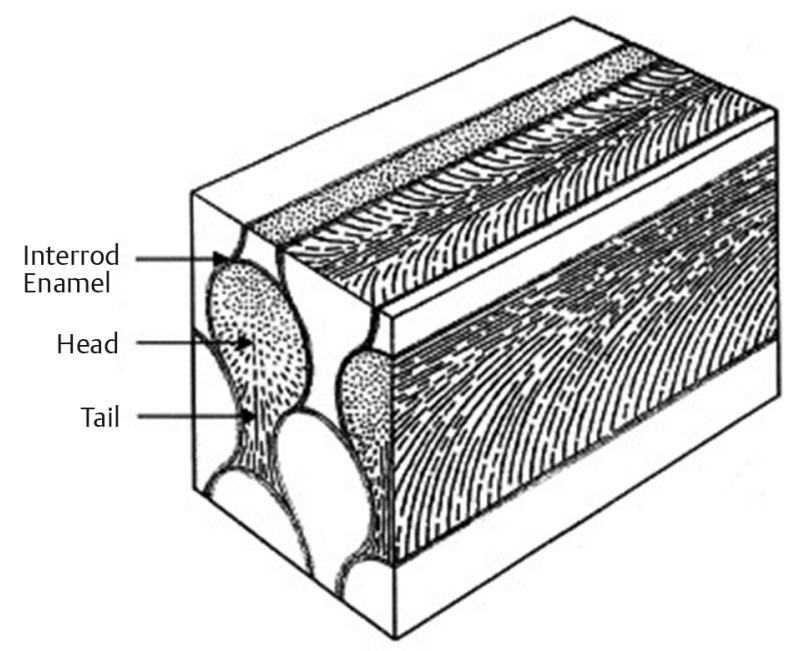

Fig. 1 Schematic drawing of enamel microstructure showing keyhole-like rods aligned in parallel. These rods measure approximately $5 \mu \mathrm{m}$ in diameter. The area in between the rods is known as interprism enamel. (Reproduced with permission of Habelitz et al ${ }^{43}$ ).
A bovine enamel prism contains a bundle of HAp fiber-like crystals measuring approximately $80 \mathrm{~nm}$ in diameter and $600 \mathrm{~nm}$ in length. ${ }^{20}$ The bovine crystals are more significant in both length and thickness than human crystals as reported in studies measuring these crystals using the transmission electron microscopy. These studies revealed that each human enamel crystal is approximately 25 to $40 \mathrm{~nm}$ thick and $70 \mathrm{~nm}$ wide, respectively. ${ }^{50,51}$ The length varied among studies ranging from 50 to $100 \mathrm{~nm}$ in diameter. ${ }^{52,53}$ The larger crystals in bovine enamel might be due to the rapid development during tooth formation. ${ }^{54}$ These large crystals contribute to the porosity of bovine enamel which causes demineralization to occur three times faster than human enamel. ${ }^{24,55}$ Demineralization of bovine enamel is influenced by the acid-exposure times; human and bovine enamel behaved similarly at short acid exposure times (1-60 seconds). However, when the exposure time was increased (1-60 minutes), bovine enamel tissue loss progressed $30 \%$ faster than human enamel. ${ }^{56}$ The porosity of bovine enamel causes a rapid diffusion of acid ions within enamel upon subjecting it to acid challenges. As the softened enamel layer increases in thickness, there is a greater distance for the acid ions and dissolution products to travel to and from the dissolving crystal surface causing demineralization to occur faster in bovine enamel as compared with human enamel. ${ }^{57}$

Wang et al also highlighted the difference in the orientation of the interprism crystals in bovine enamel compared with human enamel. The interprisms of bovine enamel are arranged in continuous plate-like structures between rows of enamel prisms. Moreover, the interprisms are perpendicular to the orientation of prism crystals at the prism/interprism decussating planes. ${ }^{20}$ In contrast, interprism crystals in human enamel appeared to "lock" the prism crystals in place $^{58}$ or have a keyhole-like arrangement. ${ }^{43}$ Therefore, the interprism/prism decussating planes do not exist. ${ }^{58}$

Although bovine enamel is a suitable substitute for human enamel in demineralization studies, it is not recommended for crack propagation studies due to its interprism/prism decussating planes which results in a weak combination of prisms causing easier crack propagation. ${ }^{20}$ Besides that, due to the prisms being parallel on the outer surface of bovine enamel as in - Fig. 2, it possesses lower bond strengths as compared

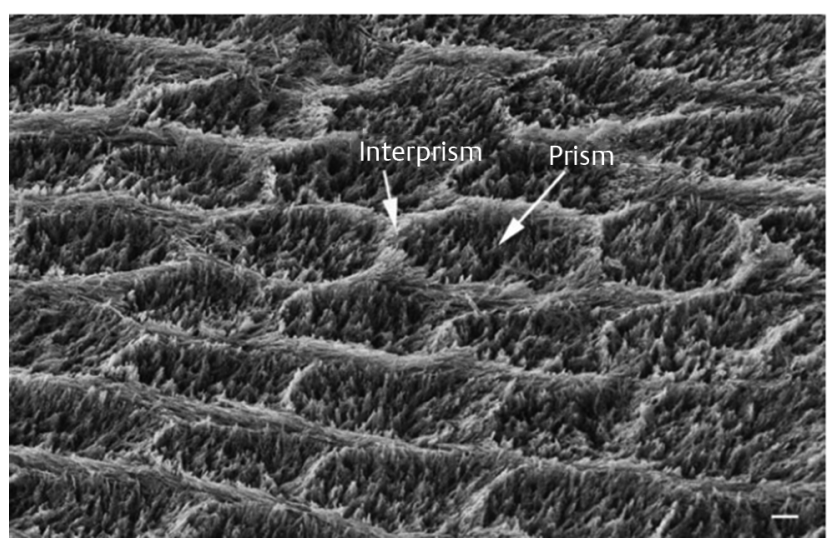

Fig. 2 SEM micrograph of parallel prism in the horizontal section of bovine enamel. A typical honeycomb pattern visible in the outer enamel $(\times 10,000$, bar $=1 \mu \mathrm{m})$. SEM, scanning electron microscopy. (Reproduced with permission of Wang et $\mathrm{al}^{20}$ ). 
with human enamel ${ }^{3}$ and might not be suitable for adhesive studies either.

\section{Enamel Specimen Preparation in Erosion and Abrasion Studies}

The main focus of this review was to establish the need for developing a reference set for polished bovine enamel samples based on surface characteristics, specifically, roughness. A search was conducted with Scopus (http://www. scopus.com) using the following keywords "enamel" AND "erosion or abrasion" AND "surface roughness." Forty-eight studies were identified under the keywords mentioned above from the year 2000 to 2020 . However, only nine studies were relevant to the preparation of bovine enamel specimens. Other studies that were not included involved human enamel (adult or primary teeth), bovine dentin, synthetic hydroxyapatite, or nondental-related enamel specimens. The information needed for this review was extracted and discussed in further detail based on these following topics: sourcing specimens; storage medium for specimens; sectioning of specimens; method of embedding specimens; lapping and polishing technique.

\section{Sourcing Specimens}

Teeth or dental hard tissues used in clinical studies should be representative of the population. Unfortunately, the environment surrounding human teeth varies in terms of fluoride therapy, salivary composition, oral hygiene, and $\operatorname{diet}^{3}$ making interpretation of findings more difficult. Bovine teeth are often used as a substitute for human teeth because they are more readily available and often originate from the same region with similar environmental factors. ${ }^{3}$ Additionally, as the bovine teeth composition has less variation than human teeth, the use of bovine teeth results in a more standardized test condition. ${ }^{59}$ Furthermore, six permanent incisors are available for extraction from cattle of 18 to 36 months of age. ${ }^{60}$

In erosive or abrasive studies, bovine enamel remains the substitute for evaluating remineralization and demineralization of enamel ${ }^{2,61}$ as it reacts similarly to acidic challenges when compared with human enamel, ${ }^{2}$ particularly during short exposure times. ${ }^{56}$ However, longer exposure time fastens the rate of demineralization of bovine enamel ${ }^{56}$ due to its large hydroxyapatite crystals that cause porosity within the enamel structure thus leading to increased permeability of acid ions when compared with human enamel. ${ }^{55}$ However, there is still a lack of research evaluating the influence of the surface characteristics or texture of polished human and bovine enamel on demineralization. ${ }^{9}$

\section{Storage Medium for Specimens}

The bovine enamel specimens must often be decontaminated and stored before usage as extracted teeth are a potential source of cross-contamination to personnel and laboratory equipment. ${ }^{62} \mathrm{~A}$ variety of storage media are reported in "in vitro" studies which include chloramine-T, ${ }^{9,63,64}$ tap water, ${ }^{16}$ thymol, ${ }^{10,65}$ and formaldehyde. ${ }^{13}$
Habelitz et al observed the reduction in hardness value of enamel when stored in deionized water or in calcium chloride $\left(\mathrm{Ca}-\mathrm{Cl}_{2}\right)$ buffered saline. ${ }^{43}$ The hardness value of enamel was reported to range between 3.2 and $3.7 \mathrm{GPa}$ prior to storage. However, the hardness of enamel decreased by $10 \%$ within a day of storage for both storage solutions. Furthermore, within 2 weeks, the decrease of enamel hardness was more prominent in specimens stored in $\mathrm{Ca}_{-} \mathrm{Cl}_{2}$-saline buffered solution when compared with deionized water, a reduction of hardness value of 35 and $25 \%$, respectively ${ }^{66}$ Storage solutions that have been recommended by other authors are chloramine-T and formaldehyde. Chloramine-T and formaldehyde solution are disinfectants and does not alter the mechanical properties of specimen. ${ }^{67,68}$

Another study reported the impact of storage conditions of eroded bovine enamel and dentine specimens on profilometric analysis. ${ }^{69}$ They reported that desiccated dentine causes shrinkage of exposed surface collagen and dentin bulk, thus producing different profilometric readings when compared with wet dentin samples. However, eroded enamel samples stored in wet or ambient conditions or being exposed to excessive rehydration and desiccation did not influence the performance of the profilometric measurement. ${ }^{69}$

The choice of the storage medium is essential as it might alter the mechanical properties of enamel, e.g., reduction in hardness. ${ }^{66}$ The storage condition of enamel, either wet or desiccated, does not have an implication on the measurement of roughness using a contact stylus profilometer. ${ }^{69}$

\section{Sectioning of Specimens}

Prior to embedding the bovine enamel specimens, the bovine teeth are visually ${ }^{11,13}$ or microscopically ${ }^{61}$ examined to confirm the absence of physical damage such as cracks, stains, or white spot lesions. ${ }^{11}$ There are various ways to section an intact bovine tooth to produce enamel slabs which include using a low-speed water-cooled diamond saw, ${ }^{9,16,17,63,70}$ slow-speed water-cooled drill, ${ }^{13}$ high-speed rotary diamond bur, ${ }^{65}$ or diamond disk. ${ }^{10,71}$

The dimension of the enamel slabs used in erosion or abrasion studies ranged between 4 and $10 \mathrm{~mm}$ in width and 2 and $4 \mathrm{~mm}$ in height. $13,16,17,72$ As this research involves the roughness measurement of polished bovine enamel specimens using a contact stylus profilometer, the size of the enamel slabs should be determined based on the sampling length and evaluation length, which is selected, based on the $\mathrm{Ra}$ of the specimen. - Table 2 indicates the sampling length recommended by the British Standard 1134-2:1990 for nonperiodic profiles. Nonperiodic profiles refer to surfaces that have undergone either grinding, polishing, lapping, or super-finishing. ${ }^{73}$

Field et al and Nekrashevych et al observed an Ra of 0.13 and $0.12 \mu \mathrm{m}$ for polished bovine enamel specimens at a sampling length of $0.3 \mathrm{~mm}$ and an evaluation length of $1.5 \mathrm{~mm}$. According to the British Standard BS1134-2: 1990, the Ra value that ranges between 0.1 and $2.0 \mu \mathrm{m}$ (refer - Table 2) requires a sampling length of $0.8 \mathrm{~mm} .{ }^{73}$ Furthermore, a sampling length of $0.8 \mathrm{~mm}$ requires an evaluation length that ranges between 2.40 and $8.00 \mathrm{~mm}$, as seen in - Table $\mathbf{3}$. 
Although the sampling and evaluation length chosen for both studies mentioned above ${ }^{9,10}$ might not adhere to the standard recommended by the British Standard (BS) 1134 and Mitutoyo stylus profilometer guideline, which is $0.8 \mathrm{~mm}$ (sampling length) and 2.4 to $8.0 \mathrm{~mm}$ (evaluation length), respectively, instead of 0.3 and $1.5 \mathrm{~mm}$, the Ra from both studies could serve as a guide in the selection of sampling length, evaluation length, and size of bovine enamel specimens for this research.

\section{Method of Embedding Specimens}

The bovine enamel specimens are embedded for easier handling and manipulation. ${ }^{56}$ Resins used to embed enamel specimens include styrene-based resins, ${ }^{9,16,18}$ acrylic resin, ${ }^{11,63}$ epoxy resins, ${ }^{10}$ slow-setting composite resin, ${ }^{70}$ and polyurethane. ${ }^{65}$

The casting process begins by placing the sectioned enamel specimen at the base of the mold and ensuring it is centrally located. ${ }^{74}$ The specimen can be held in place by a sticky wax to avoid movement of the specimen. Then, the casting resin is poured into a plastic mold until the desired height. ${ }^{9}$ The casting material fully sets after 24 hours. ${ }^{9,74}$ The removal of the embedded specimen from the mold requires the base to be removed before pressing it out of the plastic ring. Both surfaces of the cylindrical blocks that contain the embedded specimen should be parallel to ensure stability upon measurement, ${ }^{74}$ e.g., microhardness or contact-profilometer analysis.

\section{Lapping and Polishing Technique}

The Workshop on Methodology in Erosion Research suggested that the specimens at baseline should be carefully

Table 2 Sampling lengths for the measurement of Ra of nonperiodic profiles reproduced from British Standard BS 1134 (e.g., ground profiles)

\begin{tabular}{|l|l|l|}
\hline \multicolumn{2}{|c|}{ Ra } & $\begin{array}{l}\text { Sampling length } \\
\text { (cut-off) } \\
(\mathrm{mm})\end{array}$ \\
\hline & $\begin{array}{l}\text { Up to and } \\
\text { including }(\mu \mathrm{m})\end{array}$ & 0.08 \\
\hline 0.02 & 0.02 & 0.25 \\
\hline 0.1 & 0.1 & 0.8 \\
\hline 2.0 & 2.0 & 2.5 \\
\hline 10.0 & 10.0 & 8.0 \\
\hline
\end{tabular}

Table 3 The recommended evaluation length for each sampling length, adapted from Mitutoyo Stylus Profilometer guideline (2002)

\begin{tabular}{|l|l|}
\hline Sampling length $(\mathrm{mm})$ & Evaluation length $(\mathrm{mm})$ \\
\hline 0.08 & $0.4-2.00$ \\
\hline 0.25 & $1.25-5.00$ \\
\hline 0.80 & $2.40-8.00$ \\
\hline 2.50 & $5.00-15.00$ \\
\hline 8.00 & $16.00-40.00$ \\
\hline
\end{tabular}

defined and have a standardized polishing procedure and depth of material removed. ${ }^{19}$

Surface analysis requires the bovine enamel specimen's surface to be lapped flat. The silicon carbide abrasive papers are the most commonly used material to achieve a flat surface on samples before surface analysis. ${ }^{10,13,65}$

In erosive and abrasive studies, the lapping technique mainly involves the use of silicon carbide abrasive papers of descending coarseness denoted by the ascending grit number to produce a smooth and flat surface. Among the lapping sequence used for bovine enamel specimens are 600 grit $^{12} ; 800$ grit $^{4} ; 320,600$, and 1,200 grit $^{11} ; 400,600$, 800 grit $^{13} ; 600,800,1,000,1,200$ grit $^{64} ; 800,1,200,4,000$ grit, ${ }^{14}$ and $1,200,4,000$ grit. ${ }^{10}$ The grit number refers to the size of particles of abrading materials embedded in the silicon carbide papers which decreases as the grit number increases as summarized in - Table 4 . The particle sizes vary despite having the same grit number. For example

Table 4 Represents the standard conversion and average particle diameter for the United States CAMI (Coated Manufacturers Institute) and the European FEPA (Federation of European Producers of Abrasives) "P" grading system. The FEPA system is equivalent to the ISO 6344 standard (2011)

\begin{tabular}{|c|c|c|}
\hline $\begin{array}{l}\text { ISO/FEPA Grit } \\
\text { designation } \\
\text { (P grade) }\end{array}$ & $\begin{array}{l}\text { CAMI Grit } \\
\text { designation }\end{array}$ & $\begin{array}{l}\text { Average particle } \\
\text { diameter }(\mu \mathrm{m})\end{array}$ \\
\hline \multirow[t]{2}{*}{ P60 } & & 269 \\
\hline & 60 & 265 \\
\hline \multirow[t]{2}{*}{ P80 } & & 210 \\
\hline & 80 & 190 \\
\hline \multirow[t]{2}{*}{ P120 } & & 125 \\
\hline & 120 & 115 \\
\hline P180 & 180 & 82 \\
\hline \multirow[t]{2}{*}{ P240 } & & 58.5 \\
\hline & 240 & 53.0 \\
\hline \multirow[t]{2}{*}{ P360 } & & 40.5 \\
\hline & 320 & 36.0 \\
\hline \multirow[t]{2}{*}{ P400 } & & 35.0 \\
\hline & 360 & 28.0 \\
\hline \multirow[t]{2}{*}{ P600 } & & 25.8 \\
\hline & 400 & 23.0 \\
\hline \multirow[t]{2}{*}{ P800 } & & 21.8 \\
\hline & 500 & 20.0 \\
\hline \multirow[t]{2}{*}{ P1000 } & & 18.3 \\
\hline & 600 & 16.0 \\
\hline \multirow[t]{2}{*}{ P1200 } & & 15.3 \\
\hline & 800 & 12.6 \\
\hline P2000 & 1,000 & 10.3 \\
\hline
\end{tabular}


(refer - Table 4), ISO Grit ${ }^{75}$ designation of P600 and CAMI Grit designation of 600, although it has the same grit number of 600 , the particle size incorporated into these silicon carbide abrasive papers differs, at 25.8 and $16.0 \mu \mathrm{m}$, respectively.

The human enamel thickness for central incisors ranges from 0.89 to $1.06 \mathrm{~mm}^{76}$ whereas the enamel thickness for bovine mandibular incisors can reach up to $1.5 \mathrm{~mm} .{ }^{77}$ It is known that the flattening of specimens causes a varying degree of enamel removal between 100 and $400 \mu \mathrm{m}^{7,10,14,33,34}$ and exposure of crystallites which might be susceptible to abrasion. ${ }^{78}$ Furthermore, the lapping process causes removal of surface enamel, which is highly mineralized and $100-\mu \mathrm{m}$ thick ${ }^{33}$ resulting in an artificially elevated measurement of tooth surface loss upon acidic challenges. ${ }^{79}$

Various methods have been advocated to ensure uniformity in the removal of enamel during the flattening procedure. Several studies have suggested these following techniques for standardization of enamel removal: (1) using a micrometer to measure the depth of enamel removal $^{10}$; (2) consistent time for different polishing papers, 30 seconds for 600 and 60 seconds for 1,000, 1,200, and 4,000 silicon carbide abrasive papers ${ }^{16}$; (3) constant force, $2.83 \mathrm{~N}^{65}$; and (4) consistent time and load, $172 \mathrm{~g}$ for 30 seconds. ${ }^{18}$

Several studies have incorporated the use of polishing paste of different particle sizes after the lapping procedure to produce a smooth enamel surface..$^{15,18}$ Among the particle sizes that have been used are 0.05 to $6 \mu \mathrm{m} . .^{9,15-18}$ Furthermore, some studies advocate the use of ultrasonication of specimens to help remove debris caused by the lapping and polishing procedure. ${ }^{10,17,56,71}$

As mentioned earlier, there is a need in standardization of specimens at baseline in terms of polishing method and depth of material removed ${ }^{19}$ as there has been a variety of specimen preparation being employed in previous erosive or abrasion studies. Other factors that also need to be taken into consideration are the silicon carbide abrasive paper selected as the European FEPA (ISO 6344 standard) and the United States CAMI has different particle sizes despite having the same grit number. For the measurement of roughness of polished bovine enamel specimens undergoing profilometric analysis, the selection of sampling length and evaluation length should be based on the recommendation of the British Standard 1134:1990.

\section{Measurement of Roughness}

According to the British Standard 1134-2:1990, the mechanical method or the contact profilometer remains the most commonly used technique for measuring surface roughness as compared with the optical technology. ${ }^{73}$

\section{Contact Profilometer: Mechanical Stylus Method}

The contact profilometer is the most frequently used technique in measuring surface roughness or surface changes of dental hard tissues. ${ }^{8}$ A contact profilometer consists of a stylus that is mechanically connected to a transducer. As the stylus moves across the specimens' surface, it detects the surface deviations by producing an analogue signal that corresponds to the vertical movement of the stylus. The signal undergoes amplification, conditioning, and digitizing ${ }^{80,81}$ before analysis using a commercial imaging and statistical software. ${ }^{8}$

Roughness values obtained from the stylus profilometry are dependent on the diameter of the diamond-tipped stylus. $^{81,82}$ The radius of the stylus tip has been reported to range from 0.1 to $25 \mu \mathrm{m} .{ }^{61,81-82,83} \mathrm{~A}$ larger tip may distort surface roughness values ${ }^{82,84}$ due to the inability of the stylus tip to reach the deep narrow grooves on the surface profile ${ }^{80,82}$ as in - Fig. 3.

Furthermore, the stylus tip is also capable of making visible scratches on softer surfaces such as enamel and dentin, ${ }^{85}$ thus causing damages and measurement errors. ${ }^{84,85}$ The scratches caused by profilers were seen on eroded human enamel specimens ranging from 57.6 to $577.1 \mathrm{~nm}$ in-depth. ${ }^{86}$ The low $\mathrm{pH}$ value $(\mathrm{pH} 2.3)$ and longer exposure time to acidic solution (40 minutes) created the deepest scratch value. However, scratches were not found on the noneroded human enamel specimens that acted as the control group. ${ }^{86}$ If necessary, tolerances according to DIN ISO 8785 can be set for the profilometer to filter surface imperfections, such as cracks, scratches, and dents which are not part of the measured profile. ${ }^{87}$ Nonetheless, if the extent of damage due to the stylus is minimal and observed across all specimens, the possible differences in measurement among samples might not be affected. $^{88}$

The $\mathrm{Ra}$ of specimens determines the sampling length selection. As suggested earlier, a sampling length of $0.8 \mu \mathrm{m}$ is suitable for the bovine enamel specimens as studies have reported the Ra value ranging from $0.12^{10}$ to $0.13 \mu \mathrm{m} .{ }^{9}$ It is advisable to obtain the mean value of several observations per specimen to eliminate the variations within a specimen. ${ }^{73}$

\section{Noncontact Profilometer: Optical Method}

The optical method is a noncontact laser method that provides the same information regarding roughness as the ones provided by the contact profilometer technique. ${ }^{86}$ The optical technique is useful in generating a highly detailed image of the enamel surface. However, the laser has potential in penetrating the translucent enamel surface, thus creating a background noise which

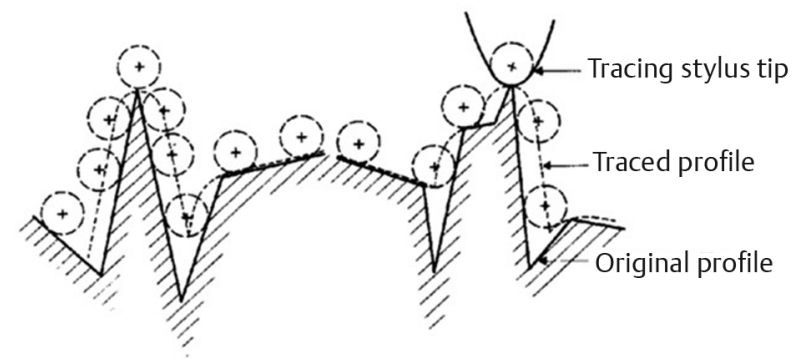

Fig. 3 The effect of stylus tip radius on the profile traced. (This image is reproduced with permission of Radhakrishnan ${ }^{82}$ ). 
affects the measurement of the surface profile. ${ }^{86}$ Furthermore, a surface that has sharp edges at the bottom of a groove causes the laser to "overshoot" hence providing misleading information regarding the surface characteristics. ${ }^{89}$

Rodriguez et al concluded that that digitization of dental materials on optical profilometers was effected by color and transparency whereby darker materials showed higher roughness values as compared with lighter materials $(p<0.05) .{ }^{90}$ The advantage of optical profilometer is that it helps to overcome the need of applying a preset force (e.g., contact profilometer) which could eventually distort the research specimens. ${ }^{90}$ However, selection of impression materials for the optical profilometry measurement is essential as darker colored impression materials produce a higher surface roughness value ${ }^{91}$ and impression materials also have the potential risk of dimensional errors while replicating the dental tissue surfaces..$^{92}$

\section{Roughness Parameters: Roughness Average and Bearing Area Parameters}

Surface roughness refers to the variation in the height of the surface relative to a reference plane. ${ }^{80}$ In dentistry, Ra is the most commonly used parameter in reporting surface roughness..$^{93}$

$\mathrm{Ra}$ is the arithmetic mean of the absolute values of the vertical deviation from the mean line through the sampling length ${ }^{80}$ also known as the center line average. ${ }^{94}$ The surface is considered rough if the deviations of the profile from the mean line are large and smooth if the deviations are small. ${ }^{60} \mathrm{Ra}$ is useful in establishing a general guideline of the surface texture of a specimen; however, it does not provide information on the surface with deep pits, sharp spikes, or the general isotropy. ${ }^{9,95}$ Field et al recommended supplementing the Ra value with BAPs which may have benefits in predicting the behavior of human or bovine enamel toward erosive or abrasion challenges. ${ }^{9}$

The BAC or Abbott-Firestone curve was first described by Abbott and Firestone in $1933 .{ }^{96}$ The BAC provides information on the peaks, valleys, and the core structure of the material by plotting the vertical deviations or height distribution of a surface in a negatively skewed manner, ${ }^{81,97}$ thus producing parameters such as peak height (Rpk), core height (Rk), valley depth (Rvk), the material ratio of peaks (Mr1), and material ratio of valleys $(\mathrm{Mr} 2)^{96}$ as in - Fig. 4 and $\boldsymbol{\imath}$ Table 5 .

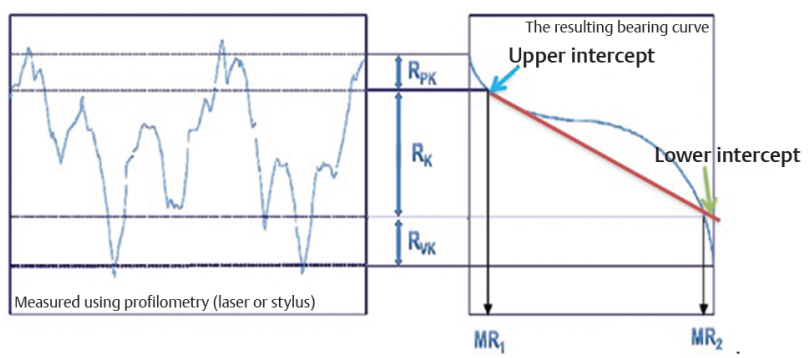

Fig. 4 The bearing area curve and parameters. (Adapted from Field et $\left.\mathrm{al}^{60}\right)$.
In engineering, the BAP is also known as the functional parameters whereby it provides information on the surface that are prone wear (Rpk), the ability of the surface to retain fluid or the lubricant retention region (Rvk), and the surface texture (Rk). ${ }^{98,99}$ The BAP serves the importance of developing a quality manufacturing process and to ensure consistent part performance, for example, the production of clutch plate design. ${ }^{95}$ In relation to dentistry, knowing the surface characteristics using the BAC may provide information of early tooth tissue loss, the ability to retain fluid components, and the long-term resistance of dental hard tissues subjected to a variety of chemical and mechanical insults. ${ }^{9}$ The proportion of eroded peak profiles (Mr1) for human enamel specimens decreased upon acid exposure suggesting that human enamel tends to suffer early enamel loss when compared with bovine enamel. ${ }^{9}$ - Fig. 5 illustrates the importance of BAP instead of $\mathrm{Ra}$ alone in evaluating the surface texture of specimens. Sample A and B had similar Ra value, but upon obtaining the BAC, sample A had deeper valleys (Rvk), whereas sample B had higher peaks (Rpk).

\section{Conclusion}

In conclusion, there might be a need in standardization of specimens at baseline based on the specimen preparation method, particularly the lapping procedure and depth of

Table 5 The description of bearing area parameters (BAP) based on - Fig. 4

\begin{tabular}{|c|c|}
\hline Bearing area parameters & Definition \\
\hline $\begin{array}{l}\text { 1. Rk (Working region or } \\
\text { the base) }\end{array}$ & $\begin{array}{l}\text { Core roughness: } \\
\text { A straight template } \\
\text { covering } 40 \% \text { of the total is } \\
\text { offered to the central and } \\
\text { flattest portion of the BAC } \\
\text { and moved until the slope } \\
\text { is a minimum (red line in } \\
\text {-Fig. 4). This straight line is } \\
\text { projected through the axes. } \\
\text { The height that separates the } \\
\text { two intercepts is known as core } \\
\text { roughness, Rk }\end{array}$ \\
\hline 2. Rpk(first region in contact) & $\begin{array}{l}\text { Peak height: } \\
\text { The height of the right-angled } \\
\text { triangle constructed from the } \\
\text { area above the intercept (blue } \\
\text { arrow in - Fig. 4). }\end{array}$ \\
\hline $\begin{array}{l}\text { 3. Rvk (lubricant retention } \\
\text { region) }\end{array}$ & $\begin{array}{l}\text { Valley depth: } \\
\text { The height of the triangle con- } \\
\text { structed below the intercept } \\
\text { (green arrow in - Fig. 4). }\end{array}$ \\
\hline 4. Mr1 (Peak material) & $\begin{array}{l}\text { Material ratio peaks: } \\
\text { The percentage of bearing area } \\
\text { (peaks) found in the limits of } \\
\text { the core profile. }\end{array}$ \\
\hline 5. Mr2 (Valley material) & $\begin{array}{l}\text { Material ratio valleys: } \\
\text { The percentage of bearing area } \\
\text { (valleys) in the limits of the } \\
\text { core profile. }\end{array}$ \\
\hline
\end{tabular}

Abbreviation: BAC, bearing area curve. 


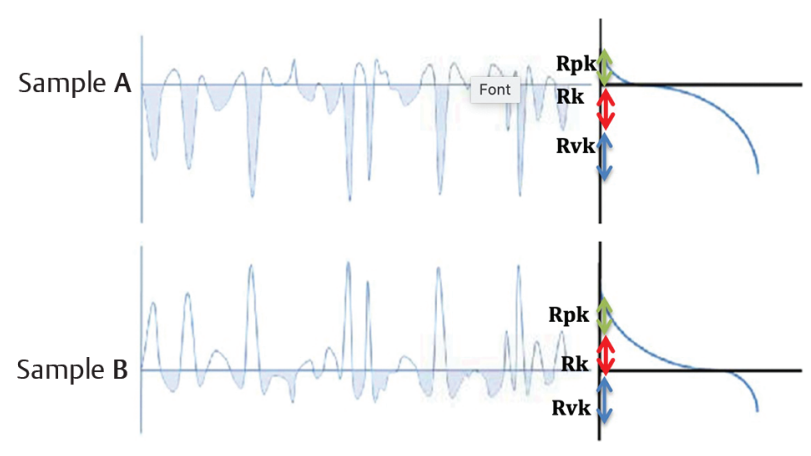

Fig. 5 Sample A and B surface with similar Ra However, sample A has deeper troughs (higher Rvk), whereas sample B has higher peaks (Rpk) on the bearing area curve. (This schematic drawing is reproduced with permission of Field et $\mathrm{al}^{60}$ ).

enamel removal. The term "flat surface" or "optically flat" used to describe the specimens at baseline has no quantitative value as it does not justify the actual surface characteristics of the prepared flattened specimen. Currently, there are no studies on the Ra and BAP of bovine or human enamel specimens at baseline that are lapped using different silicon carbide abrasive papers. Baseline specimens should incorporate Ra and BAP values as it has potential in predicting the wear or lubricating potential of these specimens. Furthermore, standardization of baseline specimens by acknowledging its surface roughness values ensures comparability of erosion and abrasion studies as different specimen preparation technique might influence the outcome or results of research.

\section{Conflict of Interest}

None declared.

\section{References}

1 Wegehaupt FJ, Widmer R, Attin T. Is bovine dentine an appropriate substitute in abrasion studies? Clin Oral Investig 2010;14(2):201-205

2 Mellberg JR. Hard-tissue substrates for evaluation of cariogenic and anti-cariogenic activity in situ.J Dent Res 1992;71:913-919

3 Oesterle LJ, Shellhart WC, Belanger GK. The use of bovine enamel in bonding studies. Am J Orthod Dentofacial Orthop 1998;114(5):514-519

4 Eisenburger M, Addy M. Evaluation of $\mathrm{pH}$ and erosion time on demineralisation. Clin Oral Investig 2001;5(2):108-111

5 West NX, Hughes JA, Addy M. Erosion of dentine and enamel in vitro by dietary acids: the effect of temperature, acid character, concentration and exposure time. J Oral Rehabil 2000;27(10):875-880

6 Hemingway CA, Parker DM, Addy M, Barbour ME. Erosion of enamel by non-carbonated soft drinks with and without toothbrushing abrasion. Br Dent J 2006;201(7):447-450, discussion 439, quiz 466

7 Hannig C, Hamkens A, Becker K, Attin R, Attin T. Erosive effects of different acids on bovine enamel: release of calcium and phosphate in vitro. Arch Oral Biol 2005;50(6):541-552

8 Las Casas EB, Bastos FS, Godoy GCD, Buono VTL. Enamel wear and surface roughness characterization using 3D profilometry. Tribol Int 2008;41(12):1232-1236
9 Field J, German M, Waterhouse P. Using bearing area parameters to quantify early erosive tooth surface changes in enamel: a pilot study. J Dent 2013;41(11):1060-1067

10 Nekrashevych Y, Hannig M, Stösser L. Assessment of enamel erosion and protective effect of salivary pellicle by surface roughness analysis and scanning electron microscopy. Oral Health Prev Dent 2004;2(1):5-11

11 Bayrak S, Tuloglu N, Bicer H, Sen Tunc E.. Effect of fluoride varnish containing CPP-ACP on preventing enamel erosion. Scanning 2017;2017-1897825

12 Hughes JA, West NX, Parker DM. van den Braak MH, Addy M. Effects of $\mathrm{pH}$ and concentration of citric, malic and lactic acids on enamel, in vitro. J Dent 2000;28(2):147-152

13 Zhou SL, Zhou J, Watanabe S, Watanabe K, Wen LY, Xuan K. In vitro study of the effects of fluoride-releasing dental materials on remineralization in an enamel erosion model. J Dent 2012;40(3):255-263

14 Ganss C, Klimek J, Schwarz N. A comparative profilometric in vitro study of the susceptibility of polished and natural human enamel and dentine surfaces to erosive demineralization. Arch Oral Biol 2000;45(10):897-902

15 Wongkhantee S, Patanapiradej V, Maneenut C, Tantbirojn D. Effect of acidic food and drinks on surface hardness of enamel, dentine, and tooth-coloured filling materials.JDent 2006;34(3): 214-220

16 Gonçalves GKM, Guglielmi CdeA, Corrêa FNP, Raggio DP, Corrêa MSNP. Erosive potential of different types of grape juices. Braz Oral Res 2012;26(5):457-463

17 Mita H, Kitasako Y, Takagaki T, Sadr A, Tagami J. Development and evaluation of a low-erosive apple juice drink with phosphoryl-oligosaccharides of calcium. Dent Mater J 2013;32(2): 212-218

18 Rodrigues MC, Mondelli RFL, Oliveira GU, Franco EB, Baseggio W, Wang L. Minimal alterations on the enamel surface by micro-abrasion: in vitro roughness and wear assessments. J Appl Oral Sci 2013;21(2):112-117

19 Shellis RP, Ganss C, Ren Y, Zero DT, Lussi A. Methodology and models in erosion research: discussion and conclusions. Caries Res 2011;45(suppl 1) :69-77

20 Wang C, Li Y, Wang X. Zhang L, Tiantang, Fu B. The enamel microstructures of bovine mandibular incisors. Anat Rec (Hoboken) 2012;295(10):1698-1706

21 Takagi S, Liao H, Chow LC. Effect of tooth-bound fluoride on enamel demineralization/ remineralization in vitro. Caries Res 2000;34(4):281-288

22 Abuabara A, Santos AJ, Aguiar FH, Lovadino JR. Evaluation of microleakage in human, bovine and swine enamels. Braz Oral Res 2004;18(4):312-316

23 Edmunds DH, Whittaker DK, Green RM. Suitability of human, bovine, equine, and ovine tooth enamel for studies of artificial bacterial carious lesions. Caries Res 1988;22(6):327-336

24 Featherstone JDB, Mellberg JR. Relative rates of progress of artificial carious lesions in bovine, ovine and human enamel. Caries Res 1981;15(1):109-114

25 Poole DFG, Shellis RP, Tyler JE. Rates of formation in vitro of dental caries-like enamel lesions in man and some non-human primates. Arch Oral Biol 1981;26(5):413-417

26 Wiegand A, Attin T. Design of erosion/abrasion studies-insights and rational concepts. Caries Res 2011;45(suppl 1):53-59

27 Turssi CP, Messias DF, Corona SM, Serra MC. Viability of using enamel and dentin from bovine origin as a substitute for human counterparts in an intraoral erosion model. Braz Dent J 2010;21(4):332-336

28 Zero DT. In situ caries models. Adv Dent Res 1995;9(3):214-230, discussion 231-234

29 Laurance-Young P, Bozec L, Gracia L, et al. A review of the structure of human and bovine dental hard tissues and their 
physicochemical behaviour in relation to erosive challenge and remineralisation. J Dent 2011;39(4):266-272

30 Pamecha S, Dayakara HR. Comparative measurement of mesiodistal width of six anterior maxillary and mandibular teeth in Rajasthan population. J Indian Prosthodont Soc 2012; 12(2):81-86

31 Ren YF, Zhao Q, Malmstrom H, Barnes V, Xu T. Assessing fluoride treatment and resistance of dental enamel to soft drink erosion in vitro: applications of focus variation 3D scanning microscopy and stylus profilometry. J Dent 2009;37(3):167-176

32 Newman HN, Poole DFG. Observations with scanning and transmission electron microscopy on the structure of human surface enamel. Arch Oral Biol 1974;19(12):1135-1143

33 Lippert F, Parker DM, Jandt KD. In vitro demineralization/ remineralization cycles at human tooth enamel surfaces investigated by AFM and nanoindentation. J Colloid Interface Sci 2004;280(2):442-448

34 Lussi A, Kohler N, Zero D, Schaffner M, Megert B. A comparison of the erosive potential of different beverages in primary and permanent teeth using an in vitro model. Eur J Oral Sci 2000;108(2):110-114

35 Hegedüs C, Bistey T, Flóra-Nagy E, Keszthelyi G, Jenei A. An atomic force microscopy study on the effect of bleaching agents on enamel surface. J Dent 1999;27(7):509-515

36 Huysmans MC, Thijssen JM. Ultrasonic measurement of enamel thickness: a tool for monitoring dental erosion? J Dent 2000; 28(3):187-191

37 Ceci M, Mirando M, Beltrami R, Chiesa M, Poggio C. Protective effect of casein phosphopeptide-amorphous calcium phosphate on enamel erosion: atomic force microscopy studies. Scanning 2015;37(5):327-334

38 Jameel RA, Khan SS, Abdul Rahim ZH, Bakri MM, Siddiqui S. Analysis of dental erosion induced by different beverages and validity of equipment for identifying early dental erosion, in vitro study. J Pak Med Assoc 2016;66(7):843-848

39 Amaechi BT, Higham SM, Edgar WM. Factors influencing the development of dental erosion in vitro: enamel type, temperature and exposure time. J Oral Rehabil 1999;26(8):624-630

40 Cherian TS, Subramaniam P, Gupta M. Erosive effect of milk, honey, cereal porridge, and millet porridge on enamel of primary teeth: an in vitro study. Indian J Dent Res 2020;31(1): 129-133

41 Giannini M, Soares CJ, de Carvalho RM. Ultimate tensile strength of tooth structures. Dent Mater 2004;20(4):322-329

42 Cuy JL, Mann AB, Livi KJ, Teaford MF, Weihs TP. Nanoindentation mapping of the mechanical properties of human molar tooth enamel. Arch Oral Biol 2002;47(4):281-291

43 Habelitz S, Marshall SJ, Marshall GW Jr, Balooch M. Mechanical properties of human dental enamel on the nanometre scale. Arch Oral Biol 2001;46(2):173-183

44 Meckel AH, Griebstein WJ, Neal RJ. Structure of mature human dental enamel as observed by electron microscopy. Arch Oral Biol 1965;10(5):775-783

45 Warshawsky H. Organization of crystals in enamel. Anat Rec 1989;224(2):242-262

46 Roy S, Basu B. Mechanical and tribological characterization of human tooth. Mater Charact 2008;59(6):747-756

$47 \mathrm{Xu} \mathrm{HH}$, Smith DT, Jahanmir S, et al. Indentation damage and mechanical properties of human enamel and dentin. J Dent Res 1998;77(3):472-480

48 Osborn JW. The nature of the Hunter-Schreger bands in enamel. Arch Oral Biol 1965;10(6):929-935

49 Zheng J, Zhou ZR, Zhang J, Li H, Yu HY. On the friction and wear behaviour of human tooth enamel and dentin. Wear 2003; 255(7-12):967-974

50 Kerebel B, Daculsi G, Kerebel LM. Ultrastructural studies of enamel crystallites. J Dent Res 1979;58(Spec Issue B): 844-851
51 Jongebloed WL, Molenaar I, Arends J. Morphology and size-distribution of sound and acid-treated enamel crystallites. Calcif Tissue Res 1975;19(2):109-123

52 White SN, Luo W, Paine ML, Fong H, Sarikaya M, Snead ML. Biological organization of hydroxyapatite crystallites into a fibrous continuum toughens and controls anisotropy in human enamel. J Dent Res 2001;80(1):321-326

53 Hannig M, Hannig C. Nanomaterials in preventive dentistry. Nat Nanotechnol 2010;5(8):565-569

54 Fridell RA, Lussi A, Crenshaw MA, Bawden JW. The in vitro uptake of fluoride by secretory and maturation stage bovine enamel. J Dent Res 1988;67(2):487-490

55 Arends J, Jongebloed WL. Crystallites dimensions of enamel. J Biol Buccale 1978;6(3):161-171

56 White AJ, Yorath C, ten Hengel V, Leary SD, Huysmans MCDNJM, Barbour ME. Human and bovine enamel erosion under 'single-drink' conditions. Eur J Oral Sci 2010;118(6):604-609

57 Flim GJ, Arends J. Diffusion of 45Ca in bovine enamel. J Dent Res 1992;71:913-919

58 Popowics TE, Rensberger JM, Herring SW. Enamel microstructure and microstrain in the fracture of human and pig molar cusps. Arch Oral Biol 2004;49(8):595-605

59 Urabe I, Nakajima S, Sano H, Tagami J. Physical properties of the dentin-enamel junction region. Am J Dent 2000;13(3):129-135

60 Field J, Waterhouse P, German M. Quantifying and qualifying surface changes on dental hard tissues in vitro. J Dent 2010;38(3):182-190

61 Attin T, Wegehaupt F, Gries D, Wiegand A. The potential of deciduous and permanent bovine enamel as substitute for deciduous and permanent human enamel: erosion-abrasion experiments. J Dent 2007;35(10):773-777

62 Humel MM, Oliveira MT, Cavalli V, Giannini M. Effect of storage and disinfection methods of extracted bovine teeth on bond strength to dentin. Braz J Oral Sci 2007;6(22):1402-1406

63 Field JC, Waterhouse PJ, German MJ. The early erosive and abrasive challenge: a profilometric, electron microscopic and microhardness study using human, bovine and ovine enamel. Eur J Prosthodont Restor Dent 2017;25(2):93-100

64 Dionysopoulos D, Tolidis K, Sfeikos T. Effect of air-abrasion pretreatment with bioactive glass $45 \mathrm{~S} 5$ on enamel surface loss after erosion/abrasion challenge. Dent Mater 2019;35(9):e193-e203

65 Jost-Brinkmann PG. The influence of air polishers on tooth enamel. An in-vitro study. J Orofac Orthop 1998;59(1):1-16

66 Habelitz S, Marshall GW Jr, Balooch M, Marshall SJ. Nanoindentation and storage of teeth. J Biomech 2002; 35(7):995-998

67 Monarca S, Garusi G, Gigola P, Spampinato L, Zani C, Sapelli PL. Decontamination of dental unit waterlines using disinfectants and filters. Minerva Stomatol 2002;51(10):451-459

68 Bland LA, Favero MS, Oxborrow GS, Aguero SM, Searcy BP, Danielson JW. Effect of chemical germicides on the integrity of hemodialyzer membranes. ASAIO Trans 1988;34(3):172-175

69 Attin T, Becker K, Roos M, Attin R, Paqué F. Impact of storage conditions on profilometry of eroded dental hard tissue. Clin Oral Investig 2009;13(4):473-478

70 Trentino AC, Soares AF, Duarte MAH, Ishikiriama SK, Mondelli RFL. Evaluation of $\mathrm{pH}$ levels and surface roughness after bleaching and abrasion tests of eight commercial products. Photomed Laser Surg 2015;33(7):372-377

71 Fujii M, Kitasako Y, Sadr A, Tagami J. Roughness and pH changes of enamel surface induced by soft drinks in vitro-applications of stylus profilometry, focus variation 3D scanning microscopy and micro pH sensor. Dent Mater J 2011;30(3):404-410

72 Turssi CP, Messias DCF, de Menezes M, Hara AT, Serra MC. Role of dentifrices on abrasion of enamel exposed to an acidic drink. Am J Dent 2005;18(4):251-255 
73 British Standard Institution. British Standard Institution Location: United Kingdom Assessment of Surface Texture: Guidance and General Information; 1990 1-17

74 Al-Salehi SK, Wood DJ, Hatton PV. The effect of 24h non-stop hydrogen peroxide concentration on bovine enamel and dentine mineral content and microhardness. J Dent 2007; 35(11):845-850

75 Federation of European Producers of Abrasives. Available at: https://fepa-abrasives.org/abrasives/. Updated 2020

76 Harris EF, Hicks JD. A radiographic assessment of enamel thickness in human maxillary incisors. Arch Oral Biol 1998; 43(10):825-831

77 Bechtle S, Habelitz S, Klocke A, Fett T, Schneider GA. The fracture behaviour of dental enamel. Biomaterials 2010;31(2):375-384

78 Slop D, de Rooij JF, Arends J. Abrasion of enamel. I. An in vitroinvestigation. Caries Res 1983;17(3):242-248

79 Blacker SM, Chadwick RG. An in vitro investigation of the erosive potential of smoothies. Br Dent J 2013;214(4):E9

80 Bhushan B, Modern Tribology Handbook Boca Raton, FL: CRC Press; 2001

81 Thomas TR, Rough Surfaces 2nd ed. Singapore: World Scientific Publishing Company; 1998

82 Radhakrishnan V. Effect of stylus radius on the roughness values measured with tracing stylus instruments. Wear 1970;16(5):325-335

83 Stachowiak GW, Batchelor AW, Stachowiak GB. Experimental methods in tribology: introduction. Tribol Ser 2004;44:1-12

$84 \mathrm{McCool}$ JI. Assessing the effect of stylus tip radius and flight on surface topography measurements. Trans Asme J Tribol 1984; 106(2):202-210

85 Chuenarrom C, Benjakul P. Comparison between a profilometer and a measuring microscope for measurement of enamel erosion. J Oral Sci 2008;50(4):475-479

86 Heurich E, Beyer M, Jandt KD, et al. Quantification of dental erosion-a comparison of stylus profilometry and confocal laser scanning microscopy (CLSM) Dent Mater 2010;26(4):326-336

87 Mitutoyo Surface Texture Parameter Manual for Mitutoyo SURFPAK Series of Surface Roughness Testers. Available at: https://www.mitutoyo.com/wp-content/uploads/2012/11/ 1984_Surf_Roughness_PG.pdf.

88 Honório HM, Rios D, Júnior ESP, de Oliveira DSB, Fior FA, Buzalaf MAR. Effect of acidic challenge preceded by food consumption on enamel erosion. Eur J Dent 2010;4(4):412-417

89 Schlueter N, Hara A, Shellis RP, Ganss C. Methods for the measurement and characterization of erosion in enamel and dentine. Caries Res 2011;45(suppl 1) :13-23

90 RodriguezJM, Curtis RV, BartlettDW.Surface roughness of impression materials and dental stones scanned by non-contacting laser profilometry. Dent Mater 2009;25(4):500-505

91 DeLong R, Pintado MR, Ko CC, Hodges JS, Douglas WH. Factors influencing optical 3D scanning of vinyl polysiloxane impression materials. J Prosthodont 2001;10(2):78-85

92 Chun JH, Pae A, Kim SH. Polymerization shrinkage strain of interocclusal recording materials. Dent Mater 2009;25(1):115-120

93 McCabe JF, Molyvda S, Rolland SL, Rusby S, Carrick TE. Twoand three-body wear of dental restorative materials. Int Dent J 2002;52(5, suppl 2):406-416

94 Gadelmawla ES, Koura MM, Maksoud TMA, Elewa IM, Soliman HH. Roughness parameters. J Mater Process Technol 2002; 123(1):133-145

95 Zecchino M, Characterizing Surface Quality: Why Average Roughness Is Not Enough. Notes of Iveco Instrument; December, 2003:24-30. Available at: https://www.bruker.com/ fileadmin/user_upload/8-PDF-Docs/SurfaceAnalysis/3DOpticalMicroscopy/ApplicationNotes/AN511-Characterizing Surface_Quality-Why_Average_Roughne.pdf

96 Abbott EJ, Firestone FA. Specifying surface quality: a method based on accurate measurement and comparison. Mech Eng 1933;55:569-572

97 Torrance AA. A simple datum for measurement of the Abbott curve of a profile and its first derivative. Tribol Int 1997; 30(3):239-244

98 Boehm H-J. Parameters for evaluating the wearing behaviour of surfaces. Int J Mach Tools Manuf 1992;32(1-2):109-113

99 Bigerelle $M$, Iost $A$. A numerical method to calculate the Abbott parameters: a wear application. Tribol Int 2007;40(9): 1319-1334 